\title{
Accuracy of transcranial colour-coded sonography in the diagnosis of anterior cerebral artery vasospasm
}

\section{Skuteczność przezczaszkowej ultrasonografii z przepływem krwi kodowanym kolorami w diagnostyce skurczu tętnicy przedniej mózgu}

Grzegorz Turek', Jan Kochanowicz',2, Robert Rutkowski', Jaroslaw Krejza, ${ }^{3,4,}$, Tomasz Lyson', Krzysztof Gorbacz', Justyna Zielinska-Turek', Zenon Mariak'

\author{
'Department of Neurosurgery, Medical University of Bialystok, Poland \\ 2Department of Invasive Neurology, Medical University of Bialystok, Poland \\ ${ }^{3}$ Department of Radiology, University of Pennsylvania, Philadelphia, USA \\ 4 Imam University, Riyadh, Kingdom of Saudi Arabia \\ ${ }^{5}$ Department of Nuclear Medicine, Medical University of Gdansk, Poland \\ ${ }^{6}$ Department of Neurology, Medical University of Bialystok, Poland
}

Neurologia i Neurochirurgia Polska 2012; 46, 3: 233-238

DOI: 10.5114/ninp.2012.29131

\begin{abstract}
Background and purpose: Transcranial colour-coded sonography (TCCS) has been proven to be a method of high performance in the diagnosis of spasm of the middle cerebral artery (MCA). Relevant data concerning the anterior cerebral artery (ACA) varies amongst studies. The aim of this study was to assess the performance of TCCS in the diagnosis of spasm affecting the ACA.

Material and methods: Ninety-two patients (39 women and 53 men, age $51 \pm 12.1$ years) were examined using TCCS before cerebral angiography. Of 184 examined ACAs, only 133 arteries could be visualized due to insufficiency of the temporal acoustic window. Therefore, only 15 out of 25 arteries in which vasospasm was diagnosed with angiography (by two neuroradiologists not informed about the sonographic findings) could be included in the analysis. Receiver operating characteristic (ROC) curves were constructed for specific blood flow velocities: peak systolic (PSV), mean (M) and enddiastolic (EDV). The area under the ROC curve was used to measure the overall diagnostic performance of TCCS.
\end{abstract}

\section{Streszczenie}

Wstęp i cel pracy: Prędkość krwi w naczyniu zwiększa się w czasie jego skurczu. Przezczaszkowa ultrasonografia dopplerowska z kodowanym kolorami przepływem krwi (transcranial colour-coded sonography - TCCS) to uznana metoda w diagnostyce skurczu tętnicy środkowej mózgu. Dane dotyczące czułości i swoistości tej metody w diagnostyce skurczu tętnicy przedniej mózgu nie są jednak jednoznaczne.

Materiał i metody: Za pomoca TCCS wykonanej bezpośrednio przed wykonaniem angiografii mózgowej zbadano 92 pacjentów. W badaniu wzięło udział 39 kobiet i 53 mężczyzn (średnia wieku: $51 \pm 12,1 \mathrm{roku}$ ). Ze 184 badanych tętnic przednich mózgu tylko 133 mogły być uwidocznione z powodu braku „okienka akustycznego” w kości skroniowej. Z tego powodu spośród 25 tętnic, w których angiograficznie stwierdzono skurcz naczyniowy (przez dwóch neuroradiologów nieznających wyników sonograficznych), tylko 15 włączono do analizy statystycznej. Krzywą charakterystyki odbiornika (ROC) wyliczono dla prędkości skurczowej, średniej oraz końcoworozkurczowej. Wielkość pola pod krzywą ROC odpowiadała skuteczności diagnostycznej TCCS.

Correspondence address: Grzegorz Turek, Department of Neurosurgery, Medical University of Bialystok, Skłodowskiej-Curie 24a, 15-276 Bialystok, Poland, phone +48 6964547 53, fax +48 8574686 26, e-mail: turekgrzegorz@vp.pl

Received: 15.04.2011; accepted: 14.02.2012 
Results: The area under the ROC curve for PSV was 0.83, which indicates good performance. The PSV threshold of $98 \mathrm{~cm} / \mathrm{s}$ corresponded to maximum accuracy and was associated with $71 \%$ sensitivity vs. $88 \%$ specificity. Average systolic blood flow velocity in the vessels with vasospasm was $129 \mathrm{~cm} / \mathrm{s}$, whereas in unaffected vessels it was $76 \mathrm{~cm} / \mathrm{s}$.

Conclusions: The accuracy of TCCS in the diagnosis of ACA spasm is relatively high - the value of the area under the ROC amounts to 0.83 . PSV performs best and the threshold of $98 \mathrm{~cm} / \mathrm{s}$ is associated with an optimal trade-off between sensitivity and specificity.

Key words: cerebral vasospasm, anterior cerebral artery, transcranial colour-coded sonography, ROC curve.

\section{Introduction}

Cerebral vasospasm is a frequent and dangerous complication of subarachnoid haemorrhage (SAH) [1-4]. Early diagnosis of spasm allows for the application of aggressive medical therapy to prevent the development of critical brain ischaemia $[1,3,5]$. Digital subtraction angiography is the most accurate reference method to detect vasospasm but it is invasive and carries the risk of stroke $[6,7]$. Because blood flow velocity increases in a vessel affected by spasm, transcranial Doppler ultrasonography (TCD), a widespread non-invasive technique, is commonly used to detect and monitor this condition, despite some methodological problems and limited accuracy [8-10]. Transcranial colour-coded sonography (TCCS), which is a newer, more technologically advanced technique, in some opinions is more suitable for the detection of cerebral vasospasm because it enables the operator to visualize the vessel in question in colour, to identify the site of the highest velocity acceleration and to obtain angle-corrected measurements of blood flow velocities [11-18]. Despite these technological advancements, imaging of the anterior cerebral artery (ACA) remains difficult due to the small calibre and relatively awkward and changeable course of this vessel.

The accuracy of TCCS in the detection of ACA spasm, however, has not yet been reliably established. The aim of our study was to assess the value of TCCS in the diagnosis of ACA vasospasm using cerebral angiography as a 'gold standard'.
Wyniki: Wartość pola pod krzywą dla prędkości skurczowej krwi wyniosła 0,83 , co odpowiada względnie wysokiej skuteczności metody w diagnostyce skurczu tętnicy przedniej mózgu. Największa skuteczność testu diagnostycznego związana jest z progiem prędkości skurczowej $98 \mathrm{~cm} / \mathrm{s}$, przy którym czułość testu wynosi $71 \%$, a swoistość - 88\%. Prędkość skurczowa w naczyniach objętych skurczem wynosiła średnio $129 \mathrm{~cm} / \mathrm{s}$, a bez skurczu $-76 \mathrm{~cm} / \mathrm{s}$.

Wnioski: Skuteczność TCCS w diagnostyce skurczu tętnicy przedniej mózgu jest względnie wysoka - wartość pola pod krzywą wynosi 0.83 . Najlepszą relację czułości do swoistości metody osiąga się, stosując diagnostyczny próg prędkości $98 \mathrm{~cm} / \mathrm{s}$.

Słowa kluczowe: skurcz naczyń mózgowych, tętnica przednia mózgu, przezczaszkowa ultrasonografia dopplerowska z kodowanym kolorami przepływem krwi, krzywa ROC.

\section{Material and methods}

We examined 92 patients in whom blood flow velocity was effectively sampled in $133 \mathrm{ACAs}$. The study group consisted of 39 women and 53 men with a mean age of $51 \pm 12.1$ years (range 17-71 years). The age of 13 patients was below 40 years, the next 57 fell into the age span of 40-60 years, and 22 were older than 60 years. All were hospitalized in the Department of Neurosurgery of the Medical University of Bialystok, due to SAH (68 patients) and intracerebral haemorrhage (ICH) (24 patients). All patients were examined clinically with digital cerebral angiography, which was performed soon after admission to detect and secure possible vascular malformation, and each of them underwent TCCS testing, directly before the angiographic examination. Testing in such an order was consequently observed to prevent situations in which any sort of treatment and/or intervention could affect the status of cerebral vasculature or hemodynamic parameters. In our department, all patients with SAH and ICH are monitored with TCCS daily and we perform the first examination as early as possible to obtain a basis for subsequent changes in the status of the cerebral vasculature. In our hands, TCCS examination takes 5-10 minutes, so neither angiography nor aneurysm handling was delayed to any significant degree. The programme of the study was approved by the Ethics Committee of the Medical University and all patients gave their fully informed consent.

A Toshiba Aplio SSA 770A scanner endowed with a 2.5 $\mathrm{MHz}$ probe was used for all sonographic examinations. The A1 segments were insonated through the 
temporal acoustic window using methods we described elsewhere [11,19]. The mean, peak systolic, and end-diastolic velocities were calculated by tracing the maximum frequency envelope of the Doppler waveform. The angle of insonation was visually adjusted to the vessel course to obtain the angle-corrected blood flow velocity. Selective intra-arterial digital subtraction angiography was performed via the Seldinger approach through the femoral artery with the Argos 2M Mecall device [20]. The image showing the most severe ACA narrowing was used for comparison with TCCS findings. Two neuroradiologists who were not familiar with the sonographic findings reviewed the angiographs to detect the presence of cerebral vasospasm. Different degrees of focal ACA narrowing [i.e. mild - up to $25 \%$ - 11 ACAs (44\%), moderate - from $25 \%$ to $50 \%-6$ ACAs $(24 \%)$ and severe - more than 50\% - 8 ACAs (32\%)] were combined to form one group: 'vessels with vasospasm'. Such grading of vasospasm was used to follow the set-up of our earlier studies with TCCS in the diagnosis of middle cerebral artery (MCA) spasm $[13,15,20]$.

Single-sided narrowing of the A1 segment was diagnosed using angiography in 23 patients, whereas double-sided narrowing was present in one patient. Altogether, 25 ACAs in 24 patients were classified as narrowed $(18.8 \%)$. In 6 of these patients, ultrasound examination was impossible due to insufficiency of the acoustic temporal window, and as a consequence they could not be included in the study group. There were 18 patients with local ACA narrowing - 11 of them had a transparent acoustic window and they were directly included in the study. In 7 patients, the entire A1 segment was classified as narrow in comparison to the opposite ACA, and these patients were referred for delayed angio-computed tomography (angio-CT) examinations. This study was performed 4-6 months after discharge by a radiologist blinded to earlier angiographic and TCCS results and revealed persistent narrowing of the A1 segment (hypoplasia or atheromatosis) in 4 patients and a return to a normal artery calibre in 3 patients. Subsequently, these 3 patients were included in the analysis. As a consequence of this approach, vasospasm of the A1 segment was diagnosed in 14 patients and in 15 ACAs.

\section{Statistical analyses}

The Shapiro-Wilk test was used for testing the distribution of continuous variables. Student's $t$-test was used for testing hypotheses about mean values of two continuous variables as the distribution of all tested variables was found to be normal.

Diagnostic accuracy of TCCS was assessed using the receiver operating characteristic (ROC) curve method $[13,20,21]$. The ROC curve is a plot of sensitivity against 1 -specificity for a family of cut points that define positive and negative values for a given test. The accuracy of a test can be quantified by calculating the area under the ROC curve.

The area under the ROC curve was computed separately for each blood flow velocity (peak systolic, mean, and end-diastolic). Blood flow velocity thresholds were established that corresponded to the best efficiency of TCCS as the diagnostic test. They were identified automatically by the statistical software to represent the best trade-off between maximum sensitivity and specificity. Both basic statistics and the ROC curves were calculated and plotted with Statistica software for Windows. A probability of less than 0.05 was considered statistically significant.

\section{Results}

Table 1 shows mean value and standard deviation of blood flow velocities calculated for the group of arteries with vasospasm as well as for the arteries which were unaffected in the angiography. Blood flow velocity in the narrowed arteries was higher in comparison to the unaffected vessels and the difference was statistically significant, as tested with Student's $t$-test.

The ROC curves for all three blood flow velocities are shown in Fig. 1. The area under the curve for peak systolic velocity was 0.83 . The mean and end-diastolic blood flow velocity showed worse performance in the diag-

Table 1. Mean value and standard deviations of particular blood flow velocities in the unaffected anterior cerebral arteries (ACAs) (Spasm -) and in the arteries with spasm (Spasm +). P - probability: the result of $t$-test

\begin{tabular}{|lcccc|}
\hline Velocity (cm/s) & No. of ACAs & Spasm (+) & Spasm (-) & P-value \\
\hline peak systolic & 133 & $129 \mathrm{~cm} / \mathrm{s}( \pm 57)$ & $76 \mathrm{~cm} / \mathrm{s}( \pm 25)$ & 0.002 \\
\hline mean & 133 & $76 \mathrm{~cm} / \mathrm{s}( \pm 36)$ & $49 \mathrm{~cm} / \mathrm{s}( \pm 18)$ & 0.008 \\
\hline end-diastolic & 133 & $48 \mathrm{~cm} / \mathrm{s}( \pm 23)$ & $32 \mathrm{~cm} / \mathrm{s}( \pm 15)$ & 0.014 \\
\hline
\end{tabular}




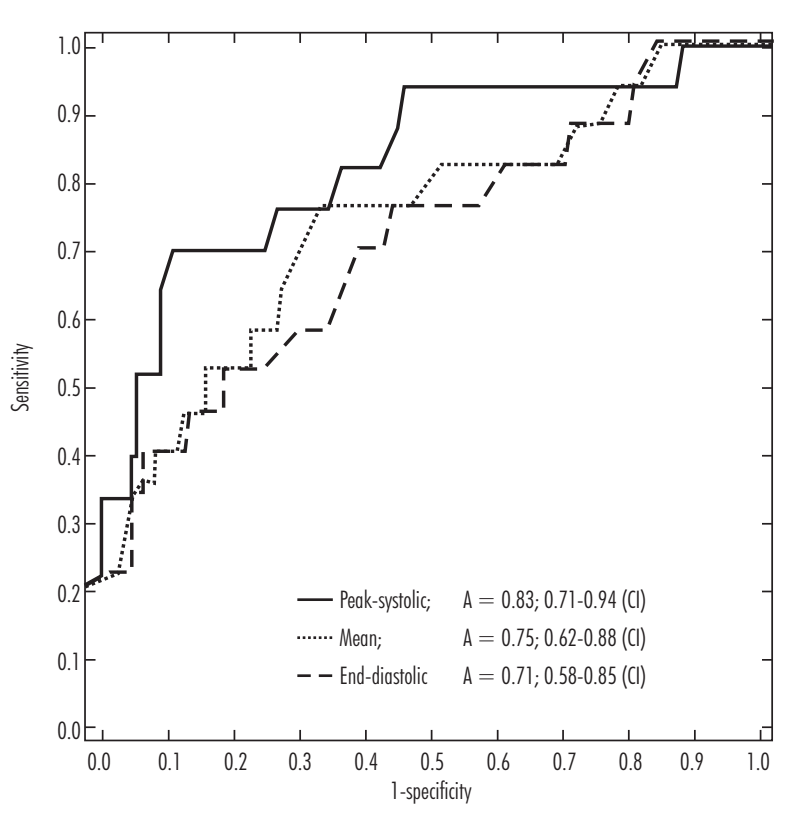

$A$ - area under the curve, $C I$ - confidence interval

Fig. 1. Receiver operating characteristic curves for peak systolic, mean, and end-diastolic blood flow velocity

nosis of vasospasm in the ACA with the area under the ROC curve 0.75 and 0.71 , respectively.

The peak systolic velocity value associated with an optimal trade-off between specificity and sensitivity was established at $98 \mathrm{~cm} / \mathrm{s}$. This value is identified by Statistica software automatically. A sensitivity of $71 \%$ and specificity of $88 \%$ corresponded to this blood flow velocity threshold (Table 2). Table 2 also summarizes optimal thresholds for mean and end-diastolic blood flow velocity together with the corresponding sensitivity and specificity for these values. In accordance with their poorer diagnostic performance, the associated values of sensitivity and specificity were also found to be lower than those related to peak systolic velocity.

\section{Discussion}

The value of TCCS in the screening of the ACA for spasm was found to be at least satisfactory in the group of patients with a sufficient temporal window. When based on peak systolic blood velocity, the calculated area under the ROC curve was 0.83 . Because this parameter is universal, it allows the diagnostic performance of different tests to be easily compared. For example, the corresponding value for mammography (which is an accepted screening examination for breast cancer) is 0.84 [22].

Our findings that the PSV value performs better in the diagnosis of ACA vasospasm than the $\mathrm{M}$ and $\mathrm{EDV}$ is in agreement with results obtained by other authors $[13,14]$. It is also in agreement with reports that enddiastolic velocity (and consequently mean velocity) is more strongly influenced than peak systolic velocity by the status of the peripheral cerebral circulation [13]. As the microcirculation can be affected by many uncontrolled factors (such as normal aging, arteriosclerosis, hormonal status, intracranial pressure, etc.), false negative results and less perfect sensitivity are more likely to appear when using the end-diastolic velocity than the peak systolic velocity values.

We found that the threshold of peak systolic velocity amounting to $98 \mathrm{~cm} / \mathrm{s}$ was associated with maximum efficiency and the trade-off between sensitivity and specificity equalled 0.71 and 0.88 , respectively. This peak systolic velocity threshold can therefore be recommended for optimal performance for the task of ACA spasm diagnosis.

To our knowledge, there is only one study available in the literature (by Proust et al.) dealing with the diagnosis of ACA spasm with colour-coded Doppler sonography [14]. Proust and colleagues identified a lower optimal peak systolic velocity threshold - only $75 \mathrm{~cm} / \mathrm{s}$ (though, interestingly, their associated sensitivity and specificity were nearly the same as in our study: 0.71 and 0.84 , respectively). To discuss this discrepancy, it should be mentioned that Proust et al. based their study on a group of only 30 patients whereas our study group was more numerous, comprising 92 patients. Also the prevalence of ACA spasm was different in both studied populations: in Proust's it was 11/30 patients whereas in ours it was $15 / 92$ patients. And it is commonly known that prevalence of a diagnosed condition in a screened population

Table 2. Optimal thresholds of blood flow velocity to diagnose spasm of the anterior cerebral artery

\begin{tabular}{|lccc|}
\hline Velocity $(\mathbf{c m} / \mathbf{s})$ & Velocity threshold & Sensitivity & Specificity \\
\hline peak systolic & $98 \mathrm{~cm} / \mathrm{s}$ & 0.71 & 0.88 \\
\hline mean & $55 \mathrm{~cm} / \mathrm{s}$ & 0.65 & 0.73 \\
\hline end-diastolic & $44 \mathrm{~cm} / \mathrm{s}$ & 0.53 & 0.77 \\
\hline
\end{tabular}


can significantly influence the result of studied diagnostic performance of a diagnostic method. It must also be noted that Proust et al. established a velocity of $75 \mathrm{~cm} / \mathrm{s}$ as an optimal diagnostic threshold for ACA spasm whereas this velocity is lower than the mean peak systolic velocity in a group of 182 healthy subjects (which was found to be $79 \mathrm{~cm} / \mathrm{s}$ ) [23]. Our optimal performance peak systolic velocity value of $98 \mathrm{~cm} / \mathrm{s}$ is by $20 \%$ higher than the mean in healthy people, but still remains within the established span of normal reference values for ACA (37$121 \mathrm{~cm} / \mathrm{s}$ ). Needless to say, this overlap with the range of normal reference values explains why the sensitivity and specificity associated with our diagnostic threshold of peak systolic velocity is less than perfect.

It is of interest to add that the authors who used conventional, i.e. 'blind', TCD for the diagnosis of ACA spasm obtained very divergent and often useless figures of sensitivity and specificity. For example, Lennihan et al. noted $13 \%$ sensitivity and $100 \%$ specificity [24]. Wozniak et al. had findings of $18 \%$ sensitivity and $65 \%$ specificity [18]. Only Kyoi Kikuo et al. reported $82 \%$ sensitivity and $71 \%$ specificity [24]. Lysakowski and Walder in their systematic review published in Stroke concluded that as to the usefulness of 'blind' transcranial Doppler in the diagnosis of ACA spasm there had been '... .lack of evidence of either accuracy or of any usefulness' [12].

Apparently, sonographic diagnosis of ACA spasm is a much more difficult task than when one is dealing with MCA. That is why serious limitations of this methodology must be clearly indicated. The first is purely anatomical. The course of the anterior cerebral artery in its A1 segment is changeable and to some extent unpredictable. The A1 usually runs in a more or less arcuate manner towards the midline, to the front and slightly upwards. Very often, both segments are asymmetrical in their calibre, length and course [25]. Especially mild to moderate vasospasm $(<50 \%)$ can escape detection because one may find it difficult to localize any relatively straight section of the artery to place the probe and to reliably measure the angle between the stream of blood and the sonographic beam. It must also be mentioned that according to some opinions vasospasm $<25 \%$ of a vessel calibre usually escapes sonographic detection, to become detectable only when approaching $50 \%$ of the initial vessel calibre.

Another problem that affects the general performance of TCCS in the diagnosis of ACA spasm is insufficiency of the temporal acoustic window. While being a problem inherited for every kind of transcranial sonography, it becomes even more serious with the visualization of the ACA. Among our 92 patients (184 anterior cerebral arteries), no artery could be visualized in 9 subjects and one artery in 33. This constitutes $28 \%$ of arteries having escaped visualization with TCCS - a sizable figure when compared to only $11 \%$ of MCAs which could not be visualized with this technique in a similar group of patients [13]. The above anatomical features (relatively small calibre, awkward and changeable course, often significant asymmetry) make the ACA apparently a much more difficult target for sonographic imaging in comparison with MCA. It was shown that even in a group of 182 healthy subjects, as many as $14 \%$ of ACAs could not be visualized with TCCS, the same being true for only $8 \%$ of MCAs [23]. The problem becomes even worse when the artery is in spasm because in this condition the course and calibre of the vessel in question changes unpredictably and the signal produced by the stream of flowing blood becomes weaker [11].

The low prevalence of moderate and severe ACA narrowing in our study group is obviously a result of random sampling of patients after $\mathrm{SAH}$ - an approach suggested by Ransohoff and Feinstein [26]. Our patients were usually referred for angiography shortly after their admission to the hospital, when vasospasm was less likely to be advanced, whereas severe vasospasm usually develops between the first and third weeks after SAH [1].

Despite recent technical refinements, sonographic diagnosis of cerebral vasospasm is by no means straightforward nor always reliable. Clinical application of TCD is still considered primarily as a useful tool for screening and not for definite diagnosis. Nevertheless, this method is irreplaceable in daily monitoring of the patient and every increase of blood flow velocity in comparison to the initial examination must be considered a sign of ongoing cerebral vasospasm.

\section{Conclusions}

1. In patients with a sufficient temporal window, the accuracy of TCCS in the diagnosis of spasm of the ACA is satisfactory, as expressed by the value of 0.83 of the area under the ROC curve. Twenty-eight percent of ACAs cannot be visualized through the temporal acoustic window.

2. The best performing TCCS parameter in the detection of ACA spasm is peak systolic velocity. Maximum efficiency (i.e. an optimal trade-off between sensitivity and specificity) is associated with a peak systolic velocity diagnostic threshold of $98 \mathrm{~cm} / \mathrm{s}$.

3. The performance of TCCS in the diagnosis of ACA spasm does not match that established earlier for the MCA. 


\section{Acknowledgments}

This study was supported by the Medical University of Bialystok grants N 3-55-772 and 3-55773.

\section{Disclosure}

Authors report no conflict of interest.

\section{References}

1. Gijn J., Rinkel G.J.E. Subarachnoid haemorrhage: diagnosis, causes and management. Brain 2001; 124: 249-278.

2. Kassell N.F., Sasaki T., Colohan A.R., et al. Cerebral vasospasm following aneurysmal subarachnoid hemorrhage. Stroke 1985; 16: 562-572.

3. Mayberg M.R., Batjer H.H., Dacey R., et al. Guidelines for the management of aneurysmal subarachnoid hemorrhage. A statement for healthcare professionals from a special writing group of the Stroke Council, American Heart Association. Stroke 1994; 25: 2315-2328.

4. Rosengart A.J., Schultheiss K.E., Tolentino J., et al. Prognostic factors for outcome in patients with aneurysmal subarachnoid hemorrhage. Stroke 2007; 38: 2315-2321.

5. Shimoda M., Oda S., Tsugane R., et al. Intracranial complications of hypervolemic therapy in patients with a delayed ischemic deficit attributed to vasospasm. J Neurosurg 1993; 78: 423-429.

6. Kochanowicz J., Lewszuk A., Kordecki K., et al. Diagnostic cerebral angiography affects the tonus of the major cerebral arteries. Med Sci Monit 2007; 13: 55-58.

7. Willinsky R.A., Taylor S.M., TerBrugge K., et al. Neurologic complications of cerebral angiography: prospective analysis of 2.899 procedures and review of the literature. Radiology 2003; 227: 522-528.

8. Aaslid R., Huber P., Nornes H. Evaluation of cerebrovascular spasm with transcranial Doppler ultrasound. J Neurosurg 1984; 60: $37-41$.

9. Compton J.S., Redmond S., Symon L. Cerebral blood velocity in subarachnoid haemorrhage: a transcranial Doppler study. J Neurol Neurosurg Psychiatry 1987; 50: 1499-1503.

10. Grolimund P., Seiler R.W., Aaslid R., et al. Evaluation of cerebrovascular disease by combined extracranial and transcranial Doppler sonography. Experience in 1,039 patients. Stroke 1987; 18: 1018-1024.

11. Krejza J., Mariak Z., Babikian V.L. Importance of angle correction in the measurement of blood flow velocity with transcranial Doppler sonography. AJNR 2001; 22: 1743-1747.

12. Lysakowski C., Walder B., Costanza M.C., et al. Transcranial doppler versus angiography in patients with vasospasm due to ruptured cerebral aneurysm. A systemic review. Stroke 2001; 32: 2292-2298.

13. Mariak Z., Krejza J., Swiercz M., et al. Accuracy of transcranial color Doppler ultrasonography in the diagnosis of middle cerebral artery spasm determined by receiver operating characteristic analysis. J Neurosurg 2002; 96: 323-330.
14. Proust F., Callonec F., Clavier E., et al. Usefulness of transcranial color-coded sonography in the diagnosis of cerebral vasospasm. Stroke 1999; 30: 1091-1098.

15. Krejza J., Mariak Z., Lewko J. Standardization of flow velocities with respect to age and sex improves the accuracy of transcranial color Doppler sonography of middle cerebral artery spasm. AJR 2003; 181: 245-252.

16. Swiat M., Weigele J., Hurst R.W., et al. Middle cerebral artery vasospasm: transcranial color-coded duplex sonography versus conventional nonimaging transcranial Doppler sonography. Crit Care Med 2009; 37: 963-968.

17. Swiercz M., Swiat M., Pawlak M., et al. Narrowing of the middle cerebral artery: artificial intelligence methods and comparison of transcranial color coded duplex sonography with conventional TCD. Ultrasound Med Biol 2010; 36: 17-28.

18. Wozniak M.A., Sloan M.A., Rothman M.I., et al. Detection of vasospasm by transcranial Doppler sonography. The challenges of the anterior and posterior cerebral arteries. J Neuroimaging 1996; 6: 87-93.

19. Krejza J., Mariak Z., Melhem E.R., et al. A guide to the identification of major cerebral arteries with transcranial color Doppler sonography. AJR 2000; 174: 1297-1303.

20. Krejza J., Kochanowicz J., Mariak Z., et al. Middle cerebral artery spasm after subarachnoid hemorrhage: detection with transcranial color-coded duplex US. Radiology 2005; 236: 621-629.

21. Zweig M.H., Campbell G. Receiver-operating characteristic (ROC) plots a fundamental evaluation tool in clinical medicine. Clin Chem 1993; 39: 561-577.

22. Beam C.A., Layde P.M., Sullivan D.C. Variability in the interpretation of screening mammograms by US radiologist. Findings from a national sample. Arch Intern Med 1996; 156: 209-213.

23. Krejza J., Mariak Z., Walecki J., et al. Transcranial color Doppler sonography of basal cerebral arteries in 182 healthy subjects: age and sex variability and normal reference values for blood flow parameters. AJR 1999; 172: 213-218.

24. Lennihan L., Petty G.W., Fink M.E., et al. Transcranial Doppler detection of cerebral artery vasospsm. J Neurol Neurosurg Psychiatry 1993; 56: 906-909.

25. Kwon H.M., Lee Y.S. Transcranial Doppler sonography evaluation of cerebral artery hypoplasia or aplasia.J Neurol Sci 2005; 231: 67-70.

26. Ransohoff D.F., Feinstein A.R. Problems of spectrum and bias in evaluating the efficacy of diagnostic tests. $N$ Engl J Med 1978; 299: 926-930. 